\title{
Ultrasonic intensification as a tool for enhanced microbial biofuel yields
}

\author{
Balakrishnan Naveena* (D, Patricia Armshaw and J. Tony Pembroke
}

\begin{abstract}
Ultrasonication has recently received attention as a novel bioprocessing tool for process intensification in many areas of downstream processing. Ultrasonic intensification (periodic ultrasonic treatment during the fermentation process) can result in a more effective homogenization of biomass and faster energy and mass transfer to biomass over short time periods which can result in enhanced microbial growth. Ultrasonic intensification can allow the rapid selective extraction of specific biomass components and can enhance product yields which can be of economic benefit. This review focuses on the role of ultrasonication in the extraction and yield enhancement of compounds from various microbial sources, specifically algal and cyanobacterial biomass with a focus on the production of biofuels. The operating principles associated with the process of ultrasonication and the influence of various operating conditions including ultrasonic frequency, power intensity, ultrasonic duration, reactor designs and kinetics applied for ultrasonic intensification are also described.
\end{abstract}

Keywords: Algal and cyanobacterial biofuels, Ultrasonic intensification, Yield enhancement, Ultrasonic reactors

\section{Background}

The utilisation of algae and cyanobacteria as cell factories for the production of biofuels has recently received considerable attention. Their ability to grow photoautotrophically and provide a renewable and sustainable biofuel source whilst also providing additional opportunities for co-product biorefinery makes them intriguing candidates [1]. There have been many reports that algal biofuel production is technically if as yet not economically viable [2-5]. Therefore, any technique that improves the efficiency of biofuel production is likely to have a significant effect on the viability of these production processes.

Algae and cyanobacteria can be metabolically engineered to produce biofuels such as ethanol $[6,7]$, biogas [8], hydrogen $[9,10]$, free fatty acids for transesterification to biodiesel $[11,12]$ and butanol [13]. Furthermore, there are several ways to convert algal or cyanobacterial biomass to fuel energy such as biochemical conversion, chemical treatment, direct combustion and thermochemical conversion [14]. Lipids can be extracted and

\footnotetext{
*Correspondence: navizauber26@gmail.com; b.naveena@ul.ie Molecular Biochemistry Laboratory, Materials and Surface Science Institute, Department of Chemical and Environmental Sciences, University of Limerick, Limerick, Ireland
}

transesterified into biodiesel while starch, glycogen and carbohydrate polymers, can be further hydrolyzed and converted into bio-ethanol [14]. Indeed following lipid extraction from Chlorococum sp. the residual biomass, used as a feedstock, has been shown to produce significant amounts of bioethanol upon fermentation with concentrations of $3.83 \mathrm{~g} \mathrm{~L}^{-1}$ achievable $[15,16]$. In this case, integration of an ultrasonication pre-treatment, known to enhance lipid extraction yields and biogas production can also be quite beneficial in disrupting the spent biomass $[8,17,18]$. This review aims to examine the beneficial aspects of ultrasonic intensification of lipid extraction, fermentation and production of biofuels.

\section{Ultrasonic process intensification: concept introduction}

Ultrasonication is a branch of acoustics that can be applied to solids, liquids and gases at frequencies above the human hearing range [19]. The frequencies applied for processes are shown in Fig. 1. Particle agitation in a liquid culture can be achieved by applying acoustic energy with frequencies ranging from $10 \mathrm{kHz}$ to $20 \mathrm{MHz}$ using ultrasonic probes, an ultrasonic bath, a flat plate or a tube type ultrasonicator [20]. The process operates by converting electrical energy into physical vibration 


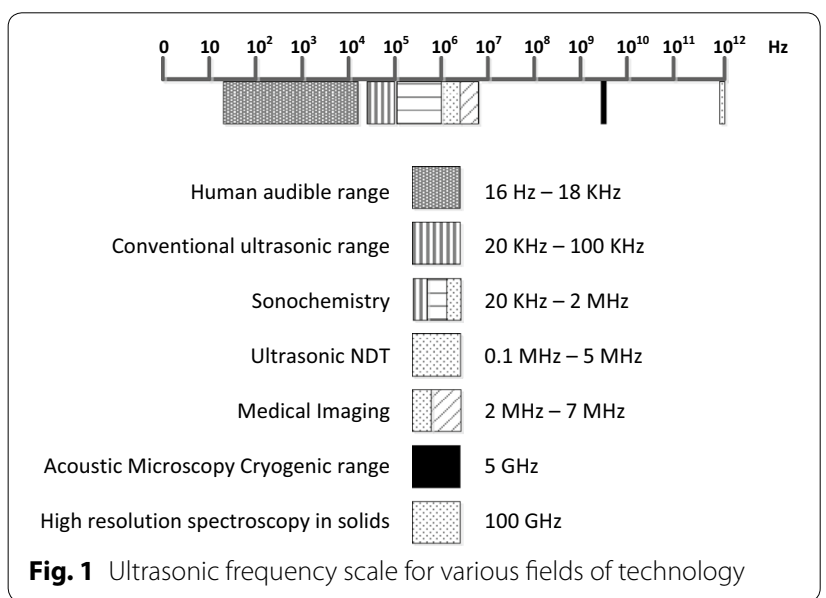

which directly influences the medium it is applied to by imparting high energy to the medium via cavitation [21]. During the vibration process, the microbubbles present in the form of nuclei are increased in size to a maximum of about 4-300 $\mathrm{mm}$ in diameter [22], and can be either stable or transient. In the case of low ultrasonic intensity, the radii of microbubbles periodically and repetitively expand and shrink causing radial oscillation within several acoustic cycles. At the point when acoustic energy has sufficient intensity, some microbubbles become unstable and when the resonant frequency of bubbles exceeds that of the ultrasonic field, the bubbles collapse within a few nanoseconds at the solid/solvent interface $(>200 \mathrm{~mm}$ ) [21] which produces microjets with a velocity $>100 \mathrm{~m} \mathrm{~s}^{-1}$ and shock waves of approximately $103 \mathrm{MPa}$ towards the solid surface of the substance in solution. This causes cavitation of the substance in the liquid medium, with the violent movement of fluid towards or away from the cavitational microbubbles defined as micro-convection [21]. The convection in the ultrasonic system has two components, i.e., microturbulence or micro-convection and shock waves [23]. The authors have stated that micro-convection is a continuous oscillatory motion of liquid medium induced by radial movement of cavitation bubble and governs the growth of the nuclei while shock waves are discrete, high pressure amplitude waves emitted by the bubble which increase the nucleation rate [23]. This micro cavitation influences the transport of fluids and solid particles within the medium and results in forces that can cause emulsification or dispersion, while the strong shockwaves and microjets generate extremely strong shear forces over those of conventional mechanical methods, and are able to scatter liquid into tiny droplets or crush solid particles into fine powders [21].

Ultrasonication which enhances biochemical reactions is termed ultrasonic process intensification [22] and can be differentiated into low and high intensity applications. In several biotechnology processes, both high and low intensity ultrasonic waves have been utilised depending on the objective of the sonication process [24]. Low intensity ultrasonic $\left(<1 \mathrm{~W} \mathrm{~cm}^{-2}\right.$ and between 1 and $\left.10 \mathrm{MHz}\right)$ intensification can be considered non-destructive as it sends ultrasonic waves through a liquid medium without causing any permanent physical or chemical change in the medium or microorganisms within. The low intensity ultrasonication can also be defined in terms of acoustic pressure amplitude. When the acoustic pressure amplitude is less than the static pressure in the medium, the bubbles undergo stable, small amplitude radial motion called "stable cavitation". The bubble motion turns transient when the acoustic pressure amplitude exceeds the static pressure in the medium. The microorganisms in the medium respond to the low energy only during the time of exposure to the ultrasonic waves and return to an equilibrium state when the ultrasonic source is removed [24]. On the other hand, high intensity ultrasonic intensification or low frequency ultrasonication (10$1000 \mathrm{~W} \mathrm{~cm}^{-2}$ and $10-100 \mathrm{kHz}$ ) which generates high pressure in the medium can disrupt microbial cellular structures [24]. This can cause the lysis of microbial cells or the formation of free radicals in chemical degradation reactions [25]. Thus, low intensity ultrasonic intensification is quite distinct and transitory when applied periodically. The type of cavitation generated during ultrasonic process intensification depends on several parameters, including amplitude, pressure, temperature, viscosity and concentration of the medium [26].

\section{Physical mechanism of ultrasound assisted processes for biofuels production}

Ultrasound causes both physical and chemical changes through the process of cavitation. Chemically, highly reactive radicals can be generated from the dissociation of the entrapped vapour molecules in a cavitation bubble [27]. Physically, cavitation can cause intense convection in a bulk medium leading to microturbulence (an intense oscillating motion of liquid with low to moderate velocities) and shock waves (high pressurised waves emitted by the bubble, with amplitudes as high as $30-50$ bar). During lipid extraction from biomass, the physical effects of ultrasonication can significantly enhance the lipid yield. Microturbulence can lead to a more efficient mixing of the biomass and solvent (without induction of shear stress), while shock waves can cause rupture of the cell wall [28]. Ultrasound can also generate intense local turbulence in the medium, pushing the extracted lipids away from the surface of the microbial cells, and thus, maintaining a constant concentration gradient for continuous diffusion of lipids from the cells [27]. 
The physical effects of ultrasonication can also enhance the transesterification process during biodiesel production [29-32]. Ultrasonication generates an enormous interfacial area between the oil and alcohol due to microturbulence leading to the formation of fine emulsions [33]. Kalva et al. [29] investigated the mechanism of the enhancement of transesterification by discriminating the physical and chemical effects of ultrasound. This was analysed by transesterifying soybean oil using methanol and sodium hydroxide as the base catalyst with ultrasound frequency set at $20 \mathrm{kHz}$ and power output of $100 \mathrm{~W}$. It was reported that the enhancement of transesterification was due to the physical effect rather than a chemical effect of ultrasound, i.e., production of radical species and acceleration of the reaction by these species [34-36]. In addition it was found that the transesterification yield increased when the alcohol to oil molar ratio was increased. This was due to the effect of low intensity microturbulence generated by the cavitation bubbles in the oil, which restricted the dispersion of oil in methanol at high alcohol to oil molar ratios [29].

Ultrasound may also enhance enzymatic reactions within the cell. Khanna et al. [30] reported that the nature of convection generated by ultrasound at raised static or ambient pressure in the medium provided oscillatory motion of liquid, accompanied by medium amplitude movement by the acoustic or shock waves emitted by the bubbles. This was concluded by investigating the mechanism of enhancement of glycerol conversion into 1,3-propanediol and ethanol using Clostridium pasteurianum MTCC 116 with the aid of ultrasonication. Mild shock waves of ultrasonication were shown to cause rapid movement of microbial cells in the fermentation broth. Inter-collisions and/or collisions with the walls of the test tube lead to the acceleration of enzymatic reactions inside the cells [30]. In addition, it was reported that the high velocity micro-streaming caused desorption of the $\mathrm{CO}_{2}$ produced in the metabolic pathway and thus favoured a faster diffusion of glycerol into the microbial cells. As a result, the overall enzymatic reaction system is expected to be substrate saturated with enzyme being the limiting reactant. During ethanol formation in this system the Michaelis constant $\left(\mathrm{K}_{\mathrm{m}}\right)$ was found to decrease with ultrasonication indicating a rise in the formation of enzyme-substrate complex. Hence, ethanol yields were found to increase from 0.024 to $0.04 \mathrm{~mol} \mathrm{~mol}^{-1}$ (i.e., $83 \%$ increase) and a decrease in substrate inhibition $\left(\mathrm{K}_{\mathrm{I}}\right)$ contributed to the enhancement of 1,3-propanediol yields from 0.017 to $0.021 \mathrm{~mol} \mathrm{~mol}^{-1}$ (30.89\% increase) [30, 36].

Ultrasonication has also been shown to enhance ethanol fermentation processes by increasing transport through the cell membrane and increasing enzymatic hydrolysis with strong micro-convection [37-40]. Recent studies have found that it could enhance the utilisation of substrate for cell growth, reduce the inhibition by substrate and decrease the specific death rate of cells leading to an increase of ethanol yield from 0.149 to $0.166 \mathrm{~g} \mathrm{~g}^{-1}$ of raw biomass [41].

\section{Ultrasonic intensification applicability within extraction processes}

Traditionally, solvent based processes are utilised for extraction of many bioactive compounds [42, 43]. However, standard extraction mechanisms such as cell maceration and soxhlet extraction have limitations such as high solvent consumption, large operating cost and extended operation times which frequently result in lower yields [44]. The application of ultrasonic intensification can allow higher yields to be generated in a shorter time, with lower energy input [45] and without adding additional reagents to the extraction. In addition, the effects of increasing temperature on the extraction components can be avoided. Such modified extraction techniques have been developed recently for the extraction of macromolecules such as polysaccharides, proteins, terpenoids, flavonoids, carotenoids and phenolic compounds [46-49]. The ultrasonic intensification process can be effectively used to improve the extraction rate by increasing the mass transfer due to the formation of microcavities leading to higher growth and product yields. Ying et al. [49] reported that ultrasonic-based extraction is associated with two main physical phenomena, acoustic cavitation and diffusion through the cell wall. The conditions associated with cavitation, an increase in temperature and pressures up to $100 \mathrm{MPa}$, produce very high shear energy waves and turbulence in the cavitation zone. The combination of these factors (pressure, heat and turbulence) is used to accelerate mass transfer in the extraction process. Ultrasonic intensification also exerts a mechanical effect which leads to enhanced diffusion of solvents into the cell wall. In pure liquids, the microbubbles retain their spherical shape during the collapse, as their surroundings are uniform [50]. However, when the microbubbles collapse near a solid surface it occurs asymmetrically and produces shock waves toward the cell wall. These waves have a strong impact on the cell surface; therefore, enhance the solvent penetration into the cell. Another effect caused by the ultrasound wave is that it can facilitate the swelling and hydration of biomass and so cause an enlargement of pores in the cell wall which can improve diffusion processes and therefore enhance mass transfer which can enhance extraction yield [50]. Hence ultrasonic intensification can provide high extraction efficiency in a short time with less solvent consumption over other extraction techniques [51]. As an example, Rocco et al. [52] reported a $73 \%$ increase in 
recovery of polychlorinated biphenyls from biomass generated through treatment of household wastewater with 30 min of ultrasonic intensification during the extraction process.

\section{Benefits of ultrasonic intensification for lipids extraction in biofuel production systems}

Algae and cyanobacteria are of interest as a renewable energy source for biofuel largely because of their autotrophic lifestyle and their potential to produce a range of additional products which can aid the economics of biofuel production [53]. For lipid production in particular, lipid extraction is required and cell disruption is necessary for lipid recovery [54]. Though several disruption methods including compression, high pressure homogenization, autoclaving, bead mill treatment, microwave treatment and magnetic stirring have been employed, both at laboratory and pilot scale, the energy requirement for those techniques is typically higher than the energy of combustion of lipid extracted [55]. See Table 1 for a comparison of these extraction methodologies.

Ultrasonic intensification has been shown to improve lipid extraction via cell disruption with more favourable economics than other disruption methods [60], enhancing the extraction of lipids by $50-500 \%$ compared to traditional methods, with a 10 fold reduction in extraction time [61]. Suganya and Renganathan [62] investigated lipid extraction from the green algae Ulva lactuca using ultrasonication and found that the yield of lipid (8.49\%), was maximised with a 6 min ultrasonic pre-treatment. Lipid extraction with Synechocystis aquatilis also demonstrated that ultrasonication resulted in higher yields of lipid, with $21.30 \%$ extracted compared to grinding (18.74 \%), osmotic shock (14.55\%) and non-disruptive methods (10.17 \%) [63]. For more examples, see Table 2 detailing the reaction conditions and lipid yields recovered from various microalgae sources using ultrasonic intensification.

Algal cell walls are typically tri-layered rigid structures with high tensile strength [66], hence the release of intra lipids can be blocked. Homogenization can affect the outer cell walls with shearing force but not the interior of the cell. Extraction of lipids from cells may occur by either diffusion of lipids across the cell wall, if the algal biomass is suspended in the solvent with higher selectivity and solubility (or large partition coefficient) for lipids or disruption of the cell wall with release of cell contents in the solvent. The diffusive mechanism is less efficient due to slow diffusion of lipid across the cell wall while disruptive mechanism results in faster extraction with high yield as it causes direct release of lipid due to the rupture of cell wall [27]. Sonication can interfere with the cell interior via shock waves produced by imploding cavitation bubbles [67]. Thus, ultrasonic intensification can be an advantageous addition for lipid extraction processes involving algae. Park et al. [68] investigated the effect of homogenisation and ultrasonication in combination on lipid extraction from Chlorella vulgaris. The initial fatty acid content of C. vulgaris was $360 \mathrm{mg} \mathrm{g}^{-1}$ cell. Lipid recovery was found to increase when both techniques were combined compared with the use of either alone. The results of the combined processes showed $100.5,123.9$, and $152.0 \mathrm{mg}$ lipid $\mathrm{g}^{-1}$ cell recovered for the 20,40 , and $60 \mathrm{~min}$ reaction times used, respectively. The yields were 5.3-fold, 6.6-fold, and 8.1-fold higher, respectively, than that of the control (single treatment by sonication or single treatment via homogenization). In this system [68], microalgal suspensions were allowed to circulate continuously between the homogenizer and ultrasonicator and it was concluded that cell walls damaged slightly by homogenization would be effectively disrupted by the subsequent ultrasonication-induced cavitation bubbles resulting in a superior extraction process [68]. When the cell concentration was increased to $40 \mathrm{~g} . \mathrm{L}^{-1}$, the lipid recovery yield for $1 \mathrm{~h}$ of sonicationassisted homogenization was increased to a very high $281.3 \mathrm{mg}$ lipid $\mathrm{g}^{-1}$ cell using the chloroform-methanol solvent. This system's treatment of high cell concentrations makes it possible to enhance lipid recovery capacity based on unit time [68].

In addition to enhancing the yield of lipids extracted from cells, low frequency ultrasonic intensification can also enhance emulsion generation with immiscible liquids which are commonly used during biodiesel production. This was confirmed via an alkali catalysed biodiesel production process performed by Ji et al. [69] which found that a $100 \%$ emulsion could be achieved within 20 min with the utilisation of a jacketed ultrasonic reactor [69]. Moreover, the beneficial effects of ultrasonication have been reported for the transesterification of triglycerides with methanol. Reaction times could be reduced, as could the catalyst requirement, the energy consumption and the alcohol to oil molar ratio [70, 71]. Because of these beneficial effects on extraction and transesterification, these processes are frequently carried out concurrently. When both lipid extraction and transesterification are carried out simultaneously, it is referred to as in situ transesterification [72]. In situ transesterification processes using microbial biomass for biodiesel production can greatly enhance the biodiesel yield, as described in Table 3.

\section{Ultrasonic intensification, utility in fermentation processes}

High and low intensity ultrasonic intensification methods are utilised to enhance industrial fermentation processes 


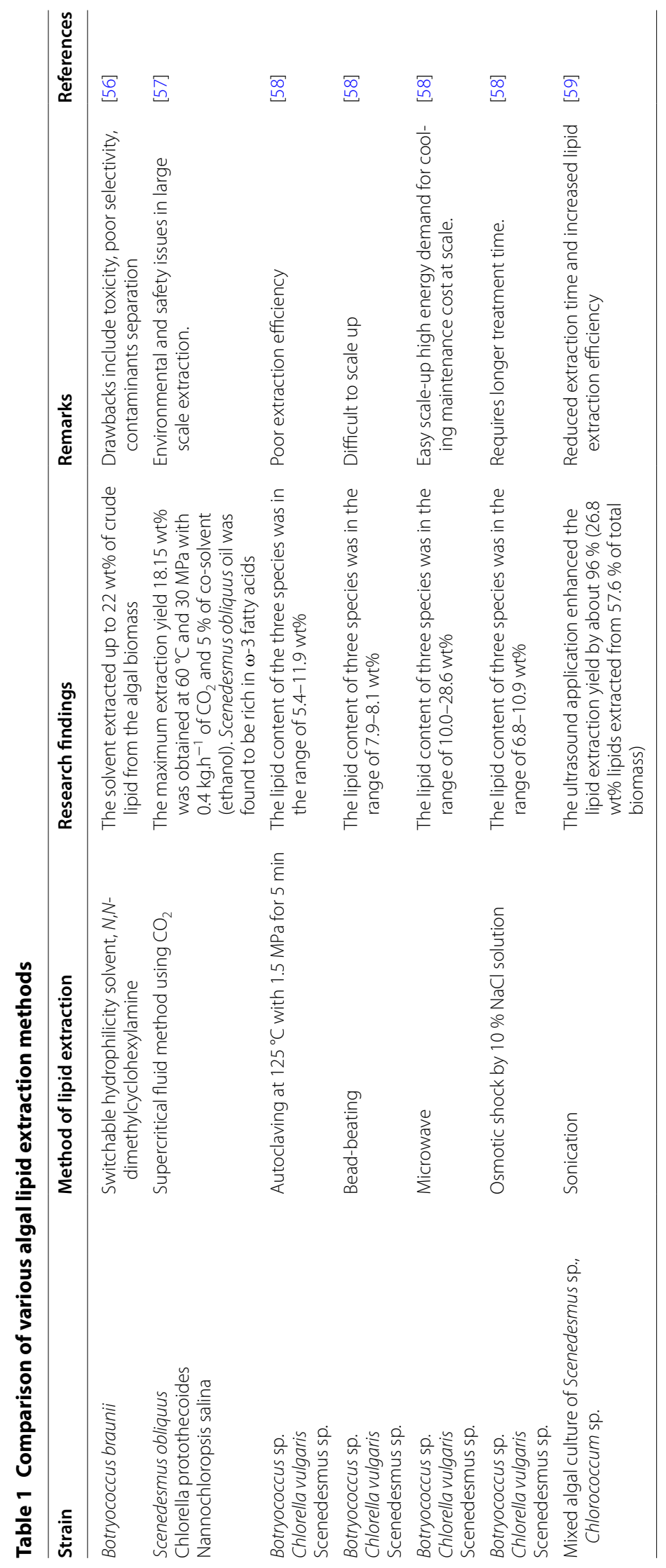


Table 2 Reaction conditions for ultrasonic intensification on extraction of lipids from various microalgae

\begin{tabular}{|c|c|c|c|c|c|c|}
\hline \multirow[t]{2}{*}{ Microalgae } & \multicolumn{4}{|c|}{ Reaction parameters } & \multirow{2}{*}{$\begin{array}{l}\text { Yield (\%) } \\
\text { (v/w) }\end{array}$} & \multirow[t]{2}{*}{ References } \\
\hline & Frequency $(\mathrm{kHz})$ & Solvent & Methodology & Time (min) & & \\
\hline Chlorella vulgaris & 10 & $\begin{array}{c}\mathrm{CHCl}_{3}-\mathrm{MeOH} \\
(1: 1)(\mathrm{V} / \mathrm{V})\end{array}$ & $\begin{array}{l}\text { Finely ground dried biomass } \\
\text { with distilled water was } \\
\text { subjected to microwave } \\
\text { oven (Sharp R-15AT } 1000 \mathrm{~W} \text {; } \\
2450 \mathrm{MHz} \text { : } 150 \text { s) and } 5 \text { min } \\
\text { ultrasonication. The lipids were } \\
\text { extracted with the solvent: bio- } \\
\text { mass ratio of 2:1. The mixture } \\
\text { was again ultrasonicated for } \\
30 \text { min }\end{array}$ & 30 & 9.82 & {$[64]$} \\
\hline C. minutissima & 10 & n-Hexane & \multirow{3}{*}{$\begin{array}{l}\text { Dried biomass (100 mg) with } \\
20 \mathrm{~mL} \text { of } n \text {-hexane was } \\
\text { subjected to ultrasonic bath } \\
\text { and further centrifugated } \\
\text { (4500 rpm for } 10 \text { min). Super- } \\
\text { natant and cell debris were } \\
\text { removed separately. }\end{array}$} & 20 & 15.5 & {$[60]$} \\
\hline Thalassiosira fluviatilis & 10 & n-Hexane & & 20 & 40.3 & {$[60]$} \\
\hline T.pseudonana & 10 & n-Hexane & & 20 & 39.5 & {$[60]$} \\
\hline Chlorella sp. & 20 & Solvent free & $\begin{array}{l}700 \mathrm{~mL} \text { of wet culture was } \\
\text { ultrasonicated directly } \\
\text { without dewatering using an } \\
\text { ultrasonic system [ultrasonic } \\
\text { processor, sonotrode, water } \\
\text { cooling jacket for the flow cell } \\
\text { (100 mL), recirculation tank for } \\
\text { feed and processed sample } \\
\text { storage and a centrifugal } \\
\text { pump for sample circulation] }\end{array}$ & $\begin{array}{l}\text { Continuous } \\
\text { system }\end{array}$ & 75 & {$[65]$} \\
\hline
\end{tabular}

Table 3 Effect of ultrasonic intensification on in situ transesterification of various microbial biomasses

\begin{tabular}{|c|c|c|c|c|c|c|c|}
\hline \multirow[t]{2}{*}{ Source } & \multirow[t]{2}{*}{ Catalyst } & \multicolumn{4}{|l|}{ Process parameters } & \multirow{2}{*}{$\begin{array}{l}\text { Biodiesel } \\
\text { yield (\%) }\end{array}$} & \multirow[t]{2}{*}{ References } \\
\hline & & $\begin{array}{l}\text { Solvent: biomass } \\
\text { ratio }(\mathrm{v} / \mathrm{w})\end{array}$ & $\begin{array}{l}\text { Frequency } \\
(\mathbf{k H z})\end{array}$ & $\begin{array}{l}\text { Temperature } \\
\left({ }^{\circ} \mathrm{C}\right)\end{array}$ & Time & & \\
\hline Chlorella vulgaris & $\mathrm{KF} / \mathrm{CaO}$ & $8: 1$ & 40 & 60 & $45 \mathrm{~min}$ & 63.49 & {$[73]$} \\
\hline $\begin{array}{l}\text { Enteromorpha } \\
\text { compressa (mac- } \\
\text { roalgae) }\end{array}$ & $\mathrm{H}_{2} \mathrm{SO}_{4}$ & $5.5: 1$ & 40 & 70 & $90 \mathrm{~min}$ & 98.89 & {$[74]$} \\
\hline Chlorella sp. & $\mathrm{H}_{2} \mathrm{SO}_{4}$ & $79: 1$ & 24 & 60 & $8 \mathrm{~h}$ & 99.9 & {$[75]$} \\
\hline $\begin{array}{l}\text { Trichosporon oleagi- } \\
\text { nosus (Yeast) }\end{array}$ & $\mathrm{NaOH}$ & $60: 1$ & 20 & 25 & $12 \mathrm{~h}$ & 92.1 & {$[72]$} \\
\hline Scenedesmus sp. & $\begin{array}{l}\text { Tungstated zirconia } \\
\qquad\left(\mathrm{WO}_{3} / \mathrm{ZrO}_{2}\right)\end{array}$ & $60: 1$ & 22.5 & 50 & $20 \mathrm{~min}$ & 71.37 & {$[76]$} \\
\hline
\end{tabular}

including those involving the production of biofuels [73]. Ultrasonic intensification has been used as a pretreatment prior to the fermentation of algal biomass for the production of bioethanol [74]. Upon ultrasonication, significant changes in the physicochemical properties of the algal cell enhance the bio-accessibility of carbohydrate substrates in the fermentation media, increasing their availability for microbial fermentation. Sonication pre-treatments (frequency $40 \mathrm{kHz}$; power output $2.2 \mathrm{~kW}$ ) for $15 \mathrm{~min}$ or longer on Scenedesmus obliquus YSW15 resulted in increasing the concentration of dissolved carbohydrate. This increased availability resulted in enhanced ethanol production by up to $5.6 \mathrm{~g} \mathrm{~L}^{-1}$. In addition, sonication can decrease algal surface hydrophobicity and increase the electrostatic repulsion among the algal debris dispersed in the aqueous solution. This can provide more facile access to the treated algal biomass, enhancing the assimilation of algal carbohydrates by anaerobic bacteria isolated from seed sludge of municipal wastewater [74]. Low intensity ultrasonication has also 
been found to promote protein production and increase cell concentration through the enhancement of cell membrane porosity [75]. For instance, upon ultrasonication, Pseudomonas aeruginosa membrane porosity has been shown to increase, resulting in the enhanced uptake of 16-doxylstearic acid (a hydrophobic antibiotic) through the cell membrane [76]. In general, such increases in cell permeability lead to enhanced diffusion rates and thereby increase the overall cell productivity and growth rate [77]. In the case of $E$. coli, the average cell count was almost doubled by the inclusion of an ultrasonication treatment $\left[8.5 \times 10^{7} \mathrm{CFU} \mathrm{m}{ }^{-1}\right.$ versus $\left.4.8 \times 10^{7} \mathrm{CFU} \mathrm{ml}^{-1}\right][77]$. Indeed the lag time $(\lambda)$ for non-ultrasonicated biomass during $\mathrm{H}_{2}$ production from the microalgae Scenedesmus obliquus YSW15 was higher than that for the ultrasonicated biomass. $\lambda$ derived from the Gompertz equation indicated that the non-ultrasonicated biomass had an average $9 \mathrm{~h}$ lag phase, which was reduced to $6 \mathrm{~h}$ after ultrasonication ( $45 \mathrm{kHz}$ with power output $2.2 \mathrm{~kW}$ ). The shorter lag phase in ultrasonicated biomass fermentation was reported due to the easy accessibility of dissolved carbohydrate to fermentative bacteria compared with the non-sonicated control [78]. The maximum $\mathrm{H}_{2}$ production was obtained from 60 min ultrasonicated biomass $\left(2419 \mathrm{~mL} \mathrm{~L}^{-1}\right)$ whereas the non-sonicated control and short-term ultrasonicated biomass for 5 min produced 1393 and $1370 \mathrm{~mL} \mathrm{~L}^{-1}$, respectively [78]. Ultrasound (at $20 \mathrm{kHz}$ ) has also been demonstrated to induce protein production, specifically thrombinase (a fibrinolytic enzyme) production from marine actinomycetes, likely due to increased mass transfer rates leading to increased nutrient uptake [79]. In conventional bioreactors, microbial cells suspended in the fermentation broth are invariably surrounded by a stagnant film of liquid [80]. This film can hinder the mass transfer of nutrients and products and can be a rate controlling factor [80]. In an ultrasonicated bioreactor, the pulsation of microbubbles of gas in the fluid generates micro-streaming [81] which can minimise the fluid boundary layer around cells located close to the bubbles [82], thus enhancing mass transfer. Ultrasonic intensification can also increase the rates of gas-liquid oxygen transfer, removal of carbon dioxide and dissolution of suspended solids. This can increase the supply of low solubility substrates and, indirectly, enhance microbial cell productivity [83]. Consequently, there are many benefits to the inclusion of a sonication treatment within fermentation processes. Ultrasonic contribution to the enhancement of fermentation yield is given in Table 4.

The length of ultrasonic treatment has a significant effect on product yields. In a study using $c$ with both continuous and intermittent ultrasonication during fermentation it was found that the ethanol concentration was increased up to $30 \mathrm{~g} \mathrm{~L}^{-1}$ with intermittent ultrasonic intensification, whereas with continuous ultrasound intensification, no increase was observed [89]. Similarly intermittent ultrasonic intensification (in fermentation broth was found to enhance the production of a fibrinolytic enzyme from Bacillus sphaericus MTCC 3672 by 1.82 fold compared to non-sonicated broth [90]. The intensity of ultrasonication can also affect yields obtained. In a study with molasses fermentation by Saccharomyces cerevisiae M30, the effect of ultrasonic intensification on ethanol production was examined. The ultrasonic frequencies were varied as 20,25 and $30 \mathrm{kHz}$ with a maximum specific ethanol production rate of $1.55 \mathrm{~g} \mathrm{~g}^{-1} \mathrm{~h}^{-1}$ being achieved at $25 \mathrm{kHz}$ [91].

While low to high intensity pulsing can enhance productivities, increased microbial exposure to ultrasonic power causes cells to become fragile and reduces microbial viability due to mechanical stress on the microbial cell [92]. The mechanical shear caused by the ultrasonic waves can disrupt the cell wall at higher duty cycles and ultimately has a lethal effect [93]. Thus, numerous studies

Table 4 Effect of ultrasonic intensification on fermentative bioenergy

\begin{tabular}{|c|c|c|c|c|c|c|}
\hline \multirow[t]{2}{*}{ Biomass } & \multirow[t]{2}{*}{ Inoculum } & \multicolumn{3}{|c|}{ Ultrasonic extraction conditions } & \multirow[t]{2}{*}{ Ethanol/hydrogen yield } & \multirow[t]{2}{*}{ References } \\
\hline & & Frequency (kHz) & Power (W) & Temperature $\left({ }^{\circ} \mathrm{C}\right)$ & & \\
\hline Parthenium hysterophorus & $\begin{array}{l}\text { Saccharomyces cerevisiae } \\
\text { MTCC } 170\end{array}$ & 35 & 35 & $30 \pm 2$ & Ethanol: $0.85 \mathrm{~g} \mathrm{~L}^{-1} \mathrm{~h}^{-1}$ & {$[37]$} \\
\hline Waste paper & Klebsiella oxytoca & 36 & 150 & - & Ethanol: $0.38 \mathrm{~g} \mathrm{~L}^{-1} \mathrm{~h}^{-1}$ & {$[84]$} \\
\hline Oil palm fronds & Saccharomyces cerevisiae & 37 & 20 & 75 & Ethanol: $3.64 \mathrm{~g} \mathrm{~L}^{-1} \mathrm{~h}^{-1}$ & {$[85]$} \\
\hline Corn meal & $\begin{array}{l}\text { Saccharomyces cerevisiae } \\
\text { var. Ellipsoideus }\end{array}$ & 40 & - & 60 & Ethanol: $3.02 \mathrm{~g} \mathrm{~L}^{-1} \mathrm{~h}^{-1}$ & {$[86]$} \\
\hline Chlorella vulgaris & Anaerobic digested sludge & 20 & 150 & 78 & $\begin{array}{l}\text { Hydrogen: } 31.9- \\
37.9 \mathrm{~mL} \mathrm{~g}^{-1} \text { dry cell } \\
\text { weight }\end{array}$ & {$[87]$} \\
\hline $\begin{array}{l}\text { Chlamydomonas rein- } \\
\text { hardtii }\end{array}$ & Thermotoga neapolitana & - & 130 & - & $860 \mathrm{~mL} \mathrm{~mL}{ }^{-1}$ culture & {$[88]$} \\
\hline
\end{tabular}


have shown that intermittent ultrasonic intensification is more advantageous, increasing product yield while keeping microbial viability high. In addition, the life span of the ultrasonic transducers is increased and temperature effects due to the transducer usage are minimised [94]. Thus, examination of the effects and the rates of ultrasound intensification utilised appear to be important for individual process strategies.

\section{Reactor design for ultrasonic intensification}

The effect of intensification on a bioprocess depends on the choice of ultrasonic parameters utilised. These include the ultrasonic mode, which can be either continuous or pulse, the frequency, the intensity, the processing temperature, the nature of the solvent utilised, the aeration and the design of reactor which determines the level and distribution of energy within the system [19]. The main parameters in ultrasonic reactor design are the type of reactor, its geometry; the design of the transducer set up and the volumetric scale of the feed stock [19]. In addition, the location of the ultrasonic probe in the reacting vessel has been found to influence the distribution of cavitational behaviour within the system [95]. The probe location is usually dependent on the reactor size and the working volume of the liquid reactants [96]. The vertical location of probes in the reactor has been shown to result in poor distribution of cavitation microbubbles with only $10 \%$ distribution reported in a $2.5 \mathrm{~L}$ reactor [97]. In contrast, the horizontal location of a probe in a reactor with $82 \%$ immersion length was shown to result in uniform cavitational behaviour over the entire reactor [98]. Another important factor is the shape and diameter of the probe tip. Ultrasonic probes with large diameter tips provide low ultrasonic energy density owing to a wide emitter surface [99]. Usage of larger tips allows higher reaction rates to be achieved. In a study utilising $B$. amyloliquefaciens producing $\alpha$-amylase, rapid deactivation of $\alpha$-amylase was observed to occur, due to the reaction between hydroxyl radicals and the enzyme but this was shown not to take place inside the bubbles. High density cavitational bubbles from a $1 \mathrm{~mm}$ sonotrode tip resulted in serious acoustic attenuation and high energy in each cavitational bubble being released when the bubbles collapsed, even though the delivered energy density was low [99]. The radiating face of the ultrasonic probe was shown to greatly affect the efficiency of enzyme inactivation in this case. It is of interest that using large sonotrodes may reduce the intensity of bubble collapse and hence are thus not recommended for intensification [99].

The amount of dissolved gas present in media undergoing sonication is a parameter which also influences the acoustic cavitation. Lowering the quantity of dissolved gas reduces the number of nuclei and thereby increases the cavitation threshold and results in a change in the type of cavitation, producing more vaporous cavities [95]. Such microbubbles collapse less violently and hence the rate of sonochemical reaction will be decreased. The selection of the correct ultrasonic frequency for the applications envisaged is also important. Higher frequency or combinations of lower frequencies is recommended for applications controlled by chemical effects whereas lower frequency is recommended for applications with physical effects [73]. The use of multiple transducers can lead to the formation of uniform cavitational behaviour and also minimise the required energy consumption in applied systems. This occurs as it would not be possible to dissipate the same power through a single probe in a large scale bioprocess operation [95]. In addition, the selection of liquids with low vapour pressure, low viscosity and high surface tension was found to enhance cavitational behaviour [95]. Therefore, the rational design of scaled-up ultrasonic reactors requires the quantitative prediction of acoustic streaming, power dissipation, mass transfer and cavitational activity in the reactor by theoretical simulations [19]. An effective scale-up of the ultrasound reactor can be achieved if the energy dissipation pattern in the reactor is known. One of the major disadvantages of ultrasound baths is the directional sensitivity of the ultrasound waves in the bath, which creates a non-homogeneous energy dissipation pattern. This can be overcome by using tubular reactors with ultrasound intensity concentrated at the core of the reactor, but any industrial scale operation has not yet been reported [100]. In an ultrasonic reactor, the input electrical energy undergoes many transformations while being converted into cavitation energy, which is dissipated in the medium to carry out the physical and chemical change. The cavitation intensity varies with the gas content of the medium [101]. The principles described above have influenced the design of several reactor types for ultrasonication-based processes. Coincidence of the compression half cycles of the two acoustic waves while using dual frequency sonochemical reactor has a favourable effect on the production of radicals, as it intensifies the transient collapse of the cavitation bubbles [102]. The dual frequency ultrasonic processor will not be able to contribute sonochemical effects, which is usually attributed to radical formation during transient cavitation. However, the moderate cavitation intensities in dual frequency reactors would favour the physical processes such as extraction and leaching [103]. Cintas et al. [104] used a reverberative flow reactor, in which two irradiation arrays made up of multiple ultrasonic probes were mounted on the upper and lower portion of a metal cuboid reactor, while liquid reactant was allowed to flow through the cuboid space $[104,105]$.The reflection of ultrasonic waves at the inner wall of the reactor chamber and its 
reverberation in the chamber caused the acoustic intensity to be multiplied, thereby giving a more non-uniform cavitation field than single probe systems. Similar technology has also been adopted in sonochemical polygonal reactors [106].

A liquid whistle ultrasonic reactor (frequency $5-30 \mathrm{kHz}$ and intensity, $1.5-2.5 \mathrm{~W} \mathrm{~cm}^{-2}$ ) which causes hydrodynamic cavitation has been widely used for industrial wastewater treatment [107], oil emulsification [108], liquid-solid mixture homogenization [19] and fat hydrolysis [109]. This type of reactor can be operated at low cost and is suitable for continuous flow reactions, with scaleup also possible [19, 104]. With effective reactor design as describe, it is possible to maximise the beneficial effects of ultrasonic intensification in a specific process while minimising cost.

\section{Kinetic analyses of ultrasonic intensification processes}

The modelling of sonoreactors is challenging due to the experimental issues relating to the effects of ultrasound [110]. The kinetic parameters of ultrasonic intensification on chemical degradation, extraction and fermentation such as ultrasonic frequency, ultrasonic intensity, ultrasonic dose and energy output so far reported are given in Table 5. Ultrasonic Intensity (UI) or acoustic energy density (AED) (sound energy per unit volume) can be evaluated calorimetrically via equation 1 as reported by Mason [111] (Table 5). The influence of the probe surface on ultrasonic intensity can also be determined by the equations 2 and 3 (Table 5). Tiehm et al. [116] hypothesised that the ultrasonic intensity related to the power supplied on the transducer area whereas the ultrasonic density related to the sample volume while the ultrasonic dose related to the energy supplied per sample volume. Though the molecular mechanism of sonochemical degradation remains subtle, there is general agreement that bond cleavage arises from the large shear gradient generated throughout the collapse of the cavitation bubbles. During sonochemical processing, once one goes beyond threshold ultrasound intensity, microbubbles are created which increase in size by absorption of acoustic energy until a critical diameter of $250 \mu \mathrm{m}$ is reached. Such bubbles become unstable and collapse violently within approximately $20 \mu$ s. Adiabatic compression raises the internal pressure to about $500 \mathrm{~atm}$ while the cavity

Table 5 Kinetic expressions derived for ultrasonic parameters

\begin{tabular}{|c|c|c|c|c|}
\hline S.No. & Parameters & Equations & Definitions & References \\
\hline 1 & $\begin{array}{l}\text { Acoustic energy density } \\
\text { (AED) }\end{array}$ & $\begin{array}{l}\mathrm{AED}=\frac{P}{V} \\
P=m c_{\mathrm{p}}\left(\frac{\mathrm{d} T}{\mathrm{~d} t}\right)_{t=0}\end{array}$ & $\begin{array}{l}P \text { absolute ultrasonic power, } V \text { volume of the medium } \\
\left(\mathrm{cm}^{3} \mathrm{~L}^{-1}\right), m \text { mass, } c_{p} \text { specific heat capacity, }(\mathrm{d} T / \mathrm{d} t) \text { range of } \\
\text { temperature change during sonication }\end{array}$ & [111] \\
\hline 2 & $\begin{array}{l}\text { Ultrasonic intensity }(\mathrm{UI}) \text { with } \\
\text { the influence of diameter } \\
\text { of the probe tip }\end{array}$ & $U \mathrm{U}=\frac{4 P}{D^{2}}$ & $P$ absolute ultrasonic power, $D$ diameter of the probe tip & {$[111]$} \\
\hline 3 & Ultrasonic intensity & $U \mathrm{U}=\frac{P}{A}$ & $\begin{array}{l}\text { Ul ultrasonic intensity, } P \text { ultrasonic power, } A \text { surface area of } \\
\text { the probe }\end{array}$ & {$[112]$} \\
\hline 4 & $\begin{array}{l}\text { Cell disruption at given } \\
\text { acoustic power }\end{array}$ & $F_{\mathrm{N}}=-\exp \left[-\left(\frac{t}{\alpha}\right)^{\beta}\right]$ & $\begin{array}{l}F_{\mathrm{N}} \text { cumulative fractions of disrupted cells at given acoustic } \\
\text { power, } t \text { time of ultrasonication, } \alpha \text { and } \beta \text { kinetic constants }\end{array}$ & [113] \\
\hline 5 & Strain rate distribution & $\begin{array}{l}\varepsilon_{\mathrm{rr}}(r)=-2 v_{\mathrm{R}} R^{2} r^{-3} \\
v_{\mathrm{R}}=\mathrm{d} R / \mathrm{d} t \dot{Q}_{\mathrm{a}} \mathrm{O}_{2} Z \\
\quad=\left(2 P_{\mathrm{h}} / 3 \rho\right)^{0.5}\left(R_{\mathrm{m}}^{3} / R^{3}-1\right)^{0.5}\end{array}$ & $\begin{array}{l}\mathcal{E}_{\mathrm{rr}} \text { strain rate distribution during cavity collapse, } v_{R} \text { bubble } \\
\text { wall velocity, } \rho \text { solvent density, } P_{h} \text { external pressure, } R_{\mathrm{m}} \\
\text { initial radius and } R \text { instantaneous radius of imploding cavity }\end{array}$ & [114] \\
\hline 6 & Specific Energy input & $E_{\mathrm{S}}=\frac{P_{t}}{V T S_{0}}$ & $\begin{array}{l}E_{s} \text { specific energy, } P \text { ultrasonic power, } t \text { ultrasonic time, } V \text { vol- } \\
\text { ume of the sample, } \mathrm{TS}_{0} \text { initial concentration of total solids }\end{array}$ & {$[115]$} \\
\hline 7 & $\begin{array}{l}\text { Actual energy produced by } \\
\text { ultrasonication }\end{array}$ & $Q_{u}=P \times t$ & $Q_{u}$ energy output, $P$ ultrasonic power, $t$ ultrasonic time & [116] \\
\hline 8 & Ultrasound dose & $\mathrm{UD}_{0}=\frac{P \times t}{V}$ & $\mathrm{UD}_{0}$ ultrasonic dose, $P$ ultrasonic power, $t$ ultrasonic time & [116] \\
\hline 9 & $\begin{array}{l}\text { Sonochemical effectiveness } \\
\text { factor }\left(\boldsymbol{e}_{\text {us }}\right)\end{array}$ & $\begin{array}{l}\boldsymbol{e}_{\mathrm{us}}=f, \eta l, \mathbb{V}_{\mathrm{us}}, T \\
\mathbb{V}_{\mathrm{us}}=V_{\mathrm{us}} / V_{\mathrm{tot}}\end{array}$ & $\begin{array}{l}f \text { applied frequency, } \eta / \text { calorimetrically determined power of } \\
\text { the transducer, } T \text { average temperature in the reactor, } \mathbb{V}_{\text {us }} \\
\text { dimensionless cavitationally active volume, } V_{\text {us }} \text { volume of } \\
\text { the reactor space affected by sonication, } V_{\text {tot }} \text { total working } \\
\text { volume }\end{array}$ & [110] \\
\hline 10 & Bubble dynamics model & $\begin{array}{l}\text { Micro-convection: } \\
V_{\text {turb }}(r, t)=\frac{R^{2}}{r^{2}}\left(\frac{d R}{d t}\right) \\
\text { Shock waves: } \\
P_{\text {AW }}(r, t)=\rho \mathrm{L} \frac{R}{r}\left[2\left(\frac{d R}{d t}\right)^{2}+R \frac{d^{2} R}{d t^{2}}\right]\end{array}$ & $\begin{array}{l}V_{\text {turb }} \text { velocity of turbulence, } P_{\text {AW }} \text { pressure amplitude of acous- } \\
\text { tic wave, } R \text { radius of the bubble, } d R / d t \text { bubble wall velocity, } \\
V_{b} \text { volume of the bubble, } \rho_{L} \text { density of the liquid }\end{array}$ & {$[31]$} \\
\hline
\end{tabular}


temperature may reach $5800 \mathrm{~K}$ [117]. If a molecular coil was to be placed beneath the imploding cavity it would be dragged along by the microstream towards the interior of the bubble while being strained by the high fluid velocity gradient [114]. However, the hydraulics are significantly different as the interior of the cavity is filled with a compressible gas with a constantly moving boundary and the applied acoustic pressure is not constant but is a sinusoidal function of time [118]. Nguyen et al. [114] have derived an expression to describe the bubble wall motion during implosive collapse as represented by the strain rate distribution $\varepsilon_{\mathrm{rr}}$ using equation 4 (Table 5). Experiments have revealed that the instantaneous radius of the imploding cavity $(\mathrm{R})$ reaches a minimum of the order of $0.5 \mu \mathrm{m}$ during the final collapse [114]. The strain rate distribution could not be altered other than by changing the ultrasonic conditions. The mechanism of ultrasound assisted acid catalysed transesterification was analysed by the quantitative estimation of physical and chemical effects through simulations of cavitation bubble dynamics. The numerical solution of the bubble dynamics model (see Table 5) can be used to estimate the composition of the bubble contents at the collapse [31]. Ultrasonic intensification can improve the biokinetic parameters such as microbial growth rate [77] during fermentation and also enhance the reaction rate of transesterification during biodiesel production. An investigation of the kinetics of ultrasonic assisted transesterfication of canola waste cooking oil showed that ultrasonication can complete the transesterification within short periods of reaction time and the activation energy was found to be $19,645 \mathrm{~J} \mathrm{~mol}^{-1} \mathrm{~K}^{-1}[119]$.

\section{Conclusion}

Although research carried out to date has indicated the utility of ultrasonication for enhancement in numerous applications, there remain many factors that require further analysis for a complete optimisation of ultrasonicbased processes particularly with a focus on improving biofuel yields from either extractive or fermentation processes.

Ultrasonic intensification can offer several advantages during bioprocessing; these include low operating cost [120] compared to other enhancing treatment options, simplicity of operation and modest power requirements. In addition, ultrasonic intensification does not require sophisticated equipment reformatting or intensive technical training for utilisation. Ultrasound would likely improve the productivity of many bioprocesses involving live cells via the enhancement of substrate uptake, enhanced production or growth by increasing cell porosity, and potentially enhanced release of cell components which could have important consequences for volatile components such as bioethanol.

\section{Abbreviations}

AED: acoustic energy density; EPA: eicosapentaenoic acid; UI: ultrasonic Intensity.

\section{Authors' contributions}

This review was conceived, researched and written by Balakrishnan Naveena. Patricia Armshaw participated in the generation of illustrations, discussing the literature and drafting of the manuscript. Joseph Tony Pembroke participated in devising the study, discussions and in the critical review of manuscript draft and revision of manuscript. All authors read and approved the final manuscript.

\section{Acknowledgements}

This research was conducted as part through Government of Ireland postdoctoral fellowship (Project Id: GOIPD/2014/303) and funded by Irish Research Council, Ireland.

\section{Compliance with ethical guidelines}

\section{Competing interests}

The authors declare that they have no competing interests.

Received: 19 May 2015 Accepted: 19 August 2015

Published online: 15 September 2015

\section{References}

1. Sahoo D, Elangbam G, Devi SS (2012) Using algae for carbon dioxide capture and bio- fuel production to combat climate change. Phykos 42:32-38

2. Chisti Y (2007) Biodiesel from microalgae. Biotech Adv. 25:294-306

3. Chisti Y (2008) Response to Reijnders: do biofuel from microalgae beats biofuel from terrestrial plants? Trends Biotechnol 26:351-352

4. Norskera NH, Barbosa MJ, Vermue MH, Wijffels RH (2011) Microalgal production-a close look at the economics. Biotech Adv 29:24-27

5. Sun A, Davis R, Starbuck M, Ben-Amotz A, Pate R, Pienkos PT (2011) Comparative cost analysis of algal oil production for biofuels. Energy 36:5169-5179

6. Dexter J, Fu P (2009) Metabolic engineering of cyanobacteria for ethanol production. Energy Environ Sci 2:857-864

7. Dexter J, Armshaw P, Sheahan C, Pembroke JT. The State of Autotrophic Ethanol Production in Cyanobacteria. J Appl Microbiol. 2015(In Press)

8. Gonzalez-Fernandez C, Timmers RT, Ruiz B, Molinuevo-Salces B. Ultrasound-enhanced biogas production from different substrates. In: Fang et al. (eds) Production of Biofuels and Chemicals with Ultrasound. Biofuels and Biorefineries. Springer; 2015; p 209-42

9. Hansel A, Lindblad P (1998) Towards optimization of cyanobacteria as biotechnologically relevant producers of molecular hydrogen. Appl Microbiol Biotechnol 50:153-160

10. Abdel-Basset R, Bader KP (1998) Physiological analyses of the hydrogen gas exchange in cyanobacteria. J Photochem Photobiol B Biol 43:146-151

11. Gao Y, Gregor C, Liang Y, Tang D, Tweed C (2012) Algae biodiesel-a feasibility report. Chem Cent J 6(Suppl 1):1-16

12. Kaiser BK, Carleton M, Hickman JW, Miller C, Lawson D, Budde M, Warrener P, Paredes A, Mullapudi S, Navarro P, Cross F, Roberts JM (2013) Fatty aldehydes in cyanobacteria are a metabolically flexible precursor for a diversity of biofuel products. PLoS One 8:1-11

13. Atsumi S, Higashide W, Liao JC (2009) Direct photosynthetic recycling of carbon dioxide to isobutyraldehyde. Nat Biotechnol 27:1177-1180

14. Mata TM, Martins AA, Caetano NS (2010) Microalgae for biodiesel production and other applications: a review. Renew Sust Energ Rev $14: 217-232$ 
15. Harun R, Danquah MK, Forde GM (2010) Microalgal biomass as a fermentation feedstock for bioethanol production. J Chem Tech Biot. 85:199-203

16. Ueno Y, Kurano N, Miyachi S (1998) Ethanol production by dark fermentation in the marinegreen alga Chlorococcum littorale. J Ferment Bioeng 86:38-43

17. Keris-Sen UD, Sen U, Soydemir G, Gurol MD (2014) An investigation of ultrasound effect on microalgal cell integrity and lipid extraction efficiency. Bioresour Technol 152:407-413

18. Lee JY, Yoo C, Jun SY, Ahn CY, Oh HM (2010) Comparison of several methods for effective lipid extraction from microalgae. Bioresour Technol 101(Suppl 1):75-77

19. Ensminger D, Bond LJ (2011) Ultrasonics: fundamentals, technologies, and applications, 3rd edn. CRC Press, Boca Raton

20. Luo J, Fang Z, Smith RL (2013) Ultrasound-enhanced conversion of biomass to biofuels. Prog Energ Combust 41:56-93

21. Suslick KS, Skrabalak SE (2008) Sonocatalysis. In: Ertl G, Knözinger H, Schüth F, Weitkamp J (eds) Handbook of heterogeneous catalysis. Wiley-VCH Verlag GmbH and Co. KGaA, Weinheim, pp 2007-2017

22. Ashokkumar M (2011) The characterization of acoustic cavitation bubbles-an overview. Ultrason Sonochem 18:864-872

23. Nalajala VS, Moholkar VS (2011) Investigations in the physical mechanism of sonocrystallization. Ultrason Sonochem 18:345-355

24. Feng H, Barbosa- Canovas GV, Weiss J (2011) Ultrasound technologies for food and bioprocessing. Springer, New York

25. Mason TJ (2003) Sonochemistry and sonoprocessing: the link, the trends and (probably) the future. Ultrason Sonochem 10:175-179

26. Mason TJ (1992) Practical sonochemistry: user's guide to applications in chemistry and chemical engineering. Ellis Horwood Ltd., New York

27. Ranjan A, Patil C, Moholkar VS (2010) Mechanic assessment of microalgal lipid extraction. Ind Eng Chem Res 49:2979-2985

28. Balasundaram B, Pandit AB (2001) Significance of location of enzymes on their release during microbial cell disruption. Biotechnol Bioeng 75:607-614

29. Kalva A, Sivasankar T, Moholkar VS (2009) Physical mechanism of ultrasound-assisted synthesis of biodiesel. Ind Eng Chem Res 48:534-544

30. Khanna S, Jaiswal S, Goyal A, Moholkar VS (2012) Ultrasound enhanced bioconversion of glycerol by Clostridium pasteurianum: a mechanistic investigation. Chem Eng J 200-202:416-425

31. Parker PA, Choudhary HA, Mohalkar VS (2012) Mechanistic and kinetic investigations in ultrasound assisted acid catalyzed biodiesel synthesis. Chem Eng J 187:248-260

32. Choudhury HA, Malani RS, Moholkar VS (2013) Acid catalyzed biodiesel synthesis from Jatropha oil: mechanistic aspects of ultrasonic intensification. Chem Eng J 231:262-272

33. Choudhury HA, Chakma S, Moholkar VS (2014) Mechanistic insight into sonochemical biodiesel synthesis using heterogeneous base catalyst. Ultrason Sonochem 21:169-181

34. Choudhury HA, Goswami PP, Malani RS, Moholkar VS (2014) Ultrasonic biodiesel synthesis from crude Jatropha curcas oil with heterogeneous base catalyst: mechanistic insight and statistical optimization. Ultrason Sonochem 21:1050-1064

35. Choudhury HA, Srivastava P, Moholkar VS (2014) Single-step ultrasonic synthesis of biodiesel from crude Jatropha curcas oil. AIChE J 60:1572-1581

36. Khanna S, Goyal A, Moholkar VS (2013) Mechanistic investigation of ultrasonic enhancement of glycerol bioconversion by immobilized Clostridium pasteurianum on silica support. Biotechnol Bioeng 110:1637-1645

37. Singh S, Agarwal M, Sarma S, Goyal A, Moholkar VS (2015) Mechanistic insight into ultrasound induced enhancement of simultaneous saccharification and fermentation of Parthenium hysterophorus for ethanol production. Ultrason Sonochem 26:249-256

38. Bharadwaja STP, Singh S, Moholkar VS (2015) Design and optimization of a sono-hybrid process for bioethanol production from Parthenium hysterophorus. J Taiwan Inst Chem Eng. 51:71-78

39. Suresh K, Ranjan A, Singh S, Moholkar VS (2014) Mechanistic investigations in sono-hybrid techniques for rice straw pretreatment. Ultrason Sonochem 21:200-207

40. Singh S, Bharadwaja STP, Yadav PK, Moholkar VS, Goyal A (2014) Mechanistic investigation in ultrasound-assisted (Alkaline) delignification of Parthenium hysterophorus biomass. Ind Eng Chem Res 53:14241-14252
41. Singh S, Sarma S, Agarwal M, Goyal A, Moholkar VS (2015) Ultrasound enhanced ethanol production from Parthenium hysterophorus: a mechanistic investigation. Bioresour Technol 188:287-294

42. Gan CY, Latiff AA (2011) Optimisation of the solvent extraction of bioactive compounds from Parkiaspeciosa pod using response surface methodology. Food Chem 124:1277-1283

43. Shao Y, Wu Q, Duan J, Yue W, Gu W, Wang X (2014) Optimisation of the solvent extraction of bioactive compounds from LophatherumgracileBrongn. using response surface methodology and HPLC-PAD coupled with pre-column antioxidant assay. Anal. Methods 6:170-177

44. Reddy Prasad ADM, Khan (2012) Comparison of extraction techniques on extraction of Gallic acid from stem bark of Jatrophacurcas. J Applied Sci 12:1106-1111

45. Liu Z, Ma C, Yang L, Zu Y (2013) Process optimization of ultrasonicassisted extraction of arabinogalactan from dihydroquercetin extracted residues by response surface methodology and evaluation of Its antioxidant activity. J Chem 2013:1-9

46. Zhong K, Wang Q (2010) Optimization of ultrasonic extraction of polysaccharides from dried longan pulp using response surface methodology. Carbohyd Polym 80:19-25

47. Feng S, Luo B, Tao B, Chen C (2014) Ultrasonic-assisted extraction and purification of phenolic compounds from sugarcane (Saccharumofficinarum L.) rinds. Food Sci Technol 60:970-976

48. Yong-guang BI, Ding-long Y, Xiao-jun H, Yu-min LI, Min-xia H (2012) Study on ultrasonic-assisted extraction of polysaccharide of Atractylis MacroceohalaKoidz of experiment. Energy Procedia 17:1778-1785

49. Ying Z, Han X, Li J (2011) Ultrasound-assisted extraction of polysaccharides from mulberry leaves. Food Chem 127:1273-1279

50. Vinatoru M (2001) An overview of the ultrasonically assisted extraction of bioactive principles from herbs. Ultrason Sonochem 8:303-313

51. Pingret D, Tixier-Fabiano AS, Chemat F (2013) Ultrasound-assisted extraction. In: Rostagno MA, Prado JM (eds) Natural product extraction: principles and applications. RSC Publishing, Londres, pp 89-112

52. Rocco G, Toledo C, Ahumada I, Sepúlveda B, Cañete A, Richter P (2008) Determination of polychlorinated biphenyls in biosolids using continuous ultrasound-assisted pressurized solvent extraction and gas chromatography-mass spectrometry. J Chromatogr A 1193:32-36

53. Lam MK, Lee KT (2014) Scale up and commercialization of Algal cultivation and Biofuel production. In: Pandey A, Lee DJ, Chisti Y, Soccol CR (eds) Biofuels from algae. Elsevier, Amsterdam, pp 261-286

54. Lee AK, Lewis DM, Ashman PJ (2012) Disruption of microalgal cells for the extraction of lipids for biofuels: processes and specific energy requirements. Biomass Bioenerg 46:89-101

55. Lee AK, Lewis DM, Ashman PJ (2013) Force and energy requirement for microalgal cell disruption: an atomic force microscope evaluation. Bioresour Technol 128:199-206

56. Boyd AR, Champagne P, McGinn PJ, MacDougall KM, Melanson JE, Jessop PG (2012) Switchable hydrophilicity solvents for lipid extraction from microalgae for biofuel production. Bioresour Technol 118:628-632

57. Solana M, Rizza CS, Bertucco A (2014) Exploiting microalgae as a source of essential fatty acids by supercritical fluid extraction of lipids: Comparison between Scenedesmusobliquus, Chlorella protothecoides and Nannochloropsissalina. J Supercrit fluids. 92:311-318

58. Lee JY, Yoo C, Jun SY, Ahn CY, Oh HM (2010) Comparison of several methods for effective lipid extraction from microalgae. Bioresour Technol 101:75-77

59. Keris-Sen UD, Sen U, Soydemir G, Gurol MD (2014) An investigation of ultrasound effect on microalgal cell integrity and lipid extraction efficiency. Bioresour Technol 152:407-413

60. Neto AMP, Sontana de Souza RF, Leon-Nino AD, Aparecida da Costa JD, Tiburcio RS, Nunes TA, Sellare de Mello TC, Kanemoto FT, Saldanha-Correa FMP, Gianesella SMF (2013) Improvement in microalgae lipid extraction using a sonication-assisted method. Renew Energ 55:525-531

61. Suali E, Sarbatly R (2012) Conversion of microalgae to biofuel. Renew Sust Energ Rev 16:4316-4342

62. Suganya T, Renganathan S (2012) Optimization and kinetic studies on algal oil extraction from marine macroalgae Ulva lactuca. Bioresour Technol 107:319-326

63. Kaiwan-arporn P, Hai PD, Thu NT, Annachhatre AP (2012) Cultivation of cyanobacteria for extraction of lipids. Biomass Bioenerg 44:142-149 
64. Sostaric M, Klinar D, Bricelj M, Golob J, Berovic M, Likozar B (2012) Growth, lipid extraction and thermal degradation of the microalgae Chlorella vulgaris. New Biotechnol 29:325-331

65. Natarajan R, RusssellAng WM, Chen X, Voigtmann M, Lau R (2014) Lipid releasing characteristics of microalgae species through continuous ultrasonication. Bioresour Technol 158:7-11

66. Allard B, Rager MN, Templier J (2002) Occurrence of high molecular weight lipids $\left(\mathrm{C}_{80+}\right)$ in the trilaminar outer cell walls of some freshwater microalgae. A reappraisal of algaenan structure. Org Geochem 33:789-801

67. Geciova J, Bury D, Jelen P (2002) Methods for disruption of microbial cells for potential use in the dairy industry-a review. Int Dairy J 12:541-553

68. Park JY, Lee K, Choi SA, Jeong MJ, Kim B, Lee JS, Oh YK (2015) Sonication assisted homogenization system for improved lipid extraction from Chlorella vulgaris. Renew Energ 79:3-8

69. Ji J, Wang J, Li Y, Yu Y, Xu Z (2006) Preparation of biodiesel with the help of ultrasonic and hydrodynamic cavitation. Ultrasonics 44:411-414

70. Sharma YC, Singh B, Upadhyay SN (2008) Advancements in development and characterization of biodiesel: a review. Fuel 87:2355-2373

71. Badday AS, Abdullah AZ, Lee KT, Khayoon MS (2012) Intensification of biodiesel production via ultrasonic - assisted process: a critical review on fundamentals and recent development. Renew Sust Energ Rev 16:4574-4587

72. Zhang X, Yan S, Tyagi RD, Surampalli RY, Valero JR (2014) Ultrasonication aided in situ transesterification of microbial lipids to biodiesel. Bioresour Technol 169:175-180

73. Sinisterra JV (1992) Application of ultrasound to biotechnology: an overview. J. Ultrasonics 30:180-185

74. Jeon BH, Choi JA, Kim HC, Hwang JH, Abou-Shanab RA, Dempsey BA, Regan JM, Kim JR (2013) Ultrasonic disintegration of microalgal biomass and consequent improvement of bioaccessibility/bioavailability in microbial fermentation. Biotechnol Biofuels 6:1-9

75. Chaunyan D, Bochu W, Haun Z, Conglin H, Chuanren D, Wangqian L, Toyama Y, Sakanishi A (2004) Effect of low frequency ultrasonic stimulation on the secretion of riboflavin produced by Ecemotheciumashbyii. Colloid Surf B 34:7-11

76. Rapoport N, Smirnov Al, Timoshin A, Pratt AM, Pitt WG (1997) Factors affecting the permeability of Pseudomonas aeruginosa cell walls toward lipophilic compounds: effects of ultrasound and cell age. Arch BiochemBiophys 344:114-124

77. Pitt WG, Ross SA (2003) Ultrasound increases the rate of bacterial cell growth. Biotechnol Prog 19:1038-1044

78. Choi JA, Hwang JH, Dempsey BA, Shanab A, Min B, Song H, Lee DS, Kim JR, Cho Y, Hong S, Jeon BH (2011) Enhancement of fermentative bioenergy (ethanol/hydrogen) production using ultrasonication of Scenedesmus obliquus YSW15 cultivated in swine wastewater effluent. Energ Environ Sci 4:3513-3520

79. Naveena B, Sakthiselvan P, Elaiyaraju P (2012) Partha N Ultrasound induced production of thrombinase by marine actinomycetes: kinetic and optimization studies. Biochem Eng J 61:34-42

80. Chisti Y (1999) Mass transfer. Encyclopedia of bioprocess technology. In: Flickinger MC, Drew SW (eds) Fermentation, biocatalysis, and bioseparation. John Wiley, New York, pp 1607-1640

81. Nyborg WL (1982) Ultrasonic microstreaming and related phenomena. Br J Cancer 45:156-160

82. Kilby NJ, Hunter CS (1990) Repeated harvest of vacuole located secondary products from in vitro grown plant cells using $1.02 \mathrm{MHz}$ ultrasound. Appl Microbiol Biotechnol. 33:448-451

83. Chisti $Y$ (2003) Sonobioreactors: using ultrasound for enhanced microbial productivity. Trends Biotechnol 21:89-93

84. Wood BE, Aldrich HC, Ingram LO (1997) Ultrasound stimulates ethanol production during the simultaneous saccharification and fermentation of mixed waste office paper. Biotechnol Prog 13:232-237

85. Boateng CO, Lee KT (2014) Ultrasonic-assisted simultaneous saccharification and fermentation of pretreated oil palm fronds for sustainable bioethanol production. Fuel 119:285-291

86. Nikolic S, Mojovic L, Rakin M, Pejin D, Pejin J (2010) Ultrasound-assisted production of bioethanol by simultaneous saccharification and fermentation of corn meal. Food Chem 122:216-222

87. Yun YM, Jung KW, Kim DH, Oh YK, Cho SK, Shin HS (2013) Optimization of dark fermentative $\mathrm{H}_{2}$ production from microalgal biomass by combined (acid + ultrasonic) pretreatment. Bioresour Technol 141:220-226

88. Nguyen TAD, Kim KR, Nguyen MT, Kim MS, Kim D, Sim SJ (2010) Enhancement of fermentative hydrogen production from green algal biomass of Thermotoga neapolitana by various pretreatment methods. Int J Hydrogen Energ. 35:13035-13040

89. Schlafer O, Sievers M, Klotzbucher H, Onyeche TI (2000) Improvement of biological activity by low energy ultrasound assisted bioreactors. Ultrasonics 38:711-716

90. Avhad DN, Rathod VK (2014) Ultrasound stimulated production of a novel fibrinolytic enzyme. Ultrason Sonochem 21:628-633

91. Klomklieng P, Prateepasen A (2012) Molasses fermentation to ethanol by Saccharomyces cerevisiaeM30 using low ultrasonic frequency stimulation. KKU Res J. 17:950-957

92. Liu R, Li W, Sun LY, Liu CZ (2012) Improving root growth and cichoric acid derivatives production in hairy root culture of Echinacea purpurea by ultrasound treatment. Biochem Eng J. 60:62-66

93. Rahman MS (1999) Light and sound in food preservation. In: Rahman MS (ed) Handbook of food preservation. New York, Marcel Dekker, pp 673-686

94. Raskar HD, Avhad DN, Rathod VK (2014) Ultrasound assisted production of daunorubicin: process intensification approach. Chem Eng Process 77:7-12

95. Gogate PR, Sutkar VS, Pandit AB (2011) Sonochemical reactors: important design and scale up considerations with a special emphasis on heterogeneous systems. Chem Eng J 166:1066-1082

96. Asakura Y, Nishida T, Matsuoka T, Koda S (2008) Effects of ultrasonic frequency and liquid height on sonochemical efficiency of large-scale sonochemical reactors. Ultrason Sonochem 15:244-250

97. Sutkar VS, Gogate PR, Csoka L (2010) Theoretical prediction of cavitational activity distribution in sonochemical reactors. Chem Eng J 158:290-295

98. Kumar A, Gogate PR, Pandit AB (2007) Mapping the efficacy of new designs for large scale sonochemical reactors. Ultrason Sonochem 14:538-544

99. Kadkhodaee R (2008) Povey MJW. Ultrasonic inactivation of Bacillus a-amylase. I. effect of gas content and emitting face of probe. Ultrason Sonochem 15:133-142

100. Moholkar VS, Sable SP, Pandit AB (2000) Mapping the cavitation intensity in an ultrasonic bath using the acoustic emission. AIChE J 46:684-694

101. Moholkar VS, Warmoeskerken MMCG (2003) Integrated approach to optimization of an ultrasonic processor. AIChE J 49:2918-2932

102. Moholkar VS (2009) Mechanistic optimization of a dual frequency sonochemical reactor. Chem Eng Sci 64:5255-5267

103. Khanna S, Chakma S, Moholkar VS (2013) Phase diagrams for dual frequency sonic processors using organic liquid medium. Chem Eng Sci. 100:137-144

104. Cintas P, Mantegna S, Gaudino EC, Cravotto G (2010) A new pilot flow reactor for high-intensity ultrasound irradiation. Application to the synthesis of biodiesel. Ultrason Sonochem 17:985-989

105. Seymour JD, Wallace HC, Gupta RB (1997) Sonochemical reactions at $640 \mathrm{kHz}$ using an efficient reactor. Oxidation of potassium iodide. Ultrason Sonochem 4:289-293

106. Easson MW, Condon B, Dien BS, Iten L, Slopek R, Yoshioka-Tarver M, Lambert A, Smith J (2011) The application of ultrasound in the enzymatic hydrolysis of switchgrass. Appl Biochem Biotechnol 165:1322-1331

107. Chakinala AG, Gogate PR, Burgess AE, Bremner DH (2008) Treatment of industrial wastewater effluents using hydrodynamic cavitation and the advanced Fenton process. Ultrason Sonochem 15:49-54

108. Shi GB, Shi Y, inventor; Shanghai Shangao Energy Saving Sci and Technology Co Ltd, assignee. Fluidic power ultrasonic emulsifying device useful for heavy oil comprises oil inlet, oil filter, high pressure pump, water tank and filter, oil and water heating device, pre-mixer, and first and second reed whistle ultrasonic emulsifier. Chinese patent: CN201197931-Y; 25 Feb 2009 [in Chinese]

109. Davidson RS, Safdar A, Spencer JD, Robinson B (1987) Applications of ultrasound to organic chemistry. Ultrasonics 25:35-39 
110. Grčic I, Šipic A, Koprivanac N, Vrsaljko D (2012) Global parameter of ultrasound exploitation (GPUE) in the reactors for wastewater treatment by sono-Fenton oxidation. Ultrason Sonochem 19:270-279

111. Mason TJ (1990) Sonochemistry: The uses of ultrasound in chemistry. Royal Society of Chemistry, Cambridge

112. Neis U, Nickel K, Tiehm A (2000) Enhancement of anaerobic sludge digestion by ultrasonic disintegration. Water Sci Technol 42:73-80

113. Choonia HS, Lele SS (2011) $\beta$-Galactosidase release kinetics during ultrasonic disruption from Lactobacillus acidophilus isolated from fermented Eleusine coracana. Food Bioprod Process 89:288-293

114. Nguyen TQ, Kausch HH (1992) Mechanochemical degradation in transient elongational flow. Adv Polym Sci 100:73-182

115. Feng X, Lei H, Deng J, Yu Q, Li H (2009) Physical and chemical characteristics of waste activated sludge treated ultrasonically. Chem Eng Process Process Intensif 48:187-194
116. Tiehm A, Nickel K, Zellhorn M, Neis U (2001) Ultrasonic waste activated sludge disintegration for improving anaerobic stabilization. Wat Res 35:2003-2009

117. Nguyen TQ, Liang QZ, Kausch HH (1997) Kinetics of ultrasonic and transient elongational flow degradation: a comparative study. Polymer 38:3783-3793

118. Mason TJ, Lorimer JP (1989) Sonochemistry: theory, applications and uses of ultrasound in chemistry. Ellis Horwood, New York

119. Grant GE, Gude VG (2014) Kinetics of ultrasonic transesterification of waste cooking oil. Environ Prog Sustain Energy 33:1051-1058

120. Thanh LT, Okitsu K, Sadanaga Y, Takenaka N, Maeda Y, Bandow H (2010) A two step continuous ultrasound assisted production of biodiesel fuel from waste cooking oils: a practical and economical approach to produce high quality biodiesel fuel. Bioresour Technol 101:5394-5401
Submit your next manuscript to BioMed Central and take full advantage of:

- Convenient online submission

- Thorough peer review

- No space constraints or color figure charges

- Immediate publication on acceptance

- Inclusion in PubMed, CAS, Scopus and Google Scholar

- Research which is freely available for redistribution

Submit your manuscript at www.biomedcentral.com/submit 